Journal of

Cancer Research and Therapeutic Oncology

\title{
The Epicholesteryl Betulinate and the Pegylated 3' a-Cholesteryl Betulinate are Active Against Liver Carcinoma. A Case Study.
}

E. Couché ${ }^{1}$, M. Gelbcke ${ }^{2}$, A. Burny ${ }^{3}$ and J.C.Leunis ${ }^{4, *}$

${ }^{1}$ Ecole Européenne de Luxembourg,Blv Konrad Adenauer 23, L-1115 Luxembourg

${ }^{2}$ Faculty of Pharmacy, ULB, Free University of Brussels

${ }^{3}$ Molecular and Cellular Biology, University of Liège

${ }^{4}$ Jean Monnet Research Center - 1, Jean Monnet Avenue B - 1348, Louvain-la-Neuve

${ }^{\star}$ Corresponding author: J.C.Leunis, Jean Monnet Research Center - 1, Jean Monnet Avenue B - 1348, Louvain-la-Neuve; Tel: +00-32-10-810 460 ; E-mail:jleunis@hotmail.com

Received Date: August 21, 2019 Accepted Date: September 15, 2019 Published Date: September 19, 2019

Citation: E. Couché (2019) The Epicholesteryl Betulinate and the Pegylated 3' a-Cholesteryl Betulinate are Active Against Liver Carcinoma. A Case Study. A Case Study. J Cancer Res Therap Oncol 7: 1-6.

\section{Introduction}

The potential value of triterpenoids, especially pentacyclic triterpenes like betulin, betulinic acid and betulonic acid in the induction of apoptosis in malignant tumor cells has been recognized for some years now [1,2].

Betulinic acid (BetA) and betulin come from a variety of botanical sources such as the bark from Betulaceae like Betulae species, Alnus glutinosa, Corulus avellana Carpinus betulus, as well as Platanaceae like Platanus orientalis and from Rhamnaceae like Ziziphus species [3,4]. BetA and betulonic acid are thus found in many plant species, although in a low concentration compared to betulin [5]. Betulinic acid (BetA) induces apoptosis of many types of cancer cells without toxicity towards normal cells in vitro and in vivo [6].

(C)2019 The Authors. Published by the JScholar under the terms of the Creative Commons Attribution License http://creativecommons.org/licenses/ by/3.0/, which permits unrestricted use, provided the original author and source are credited. 


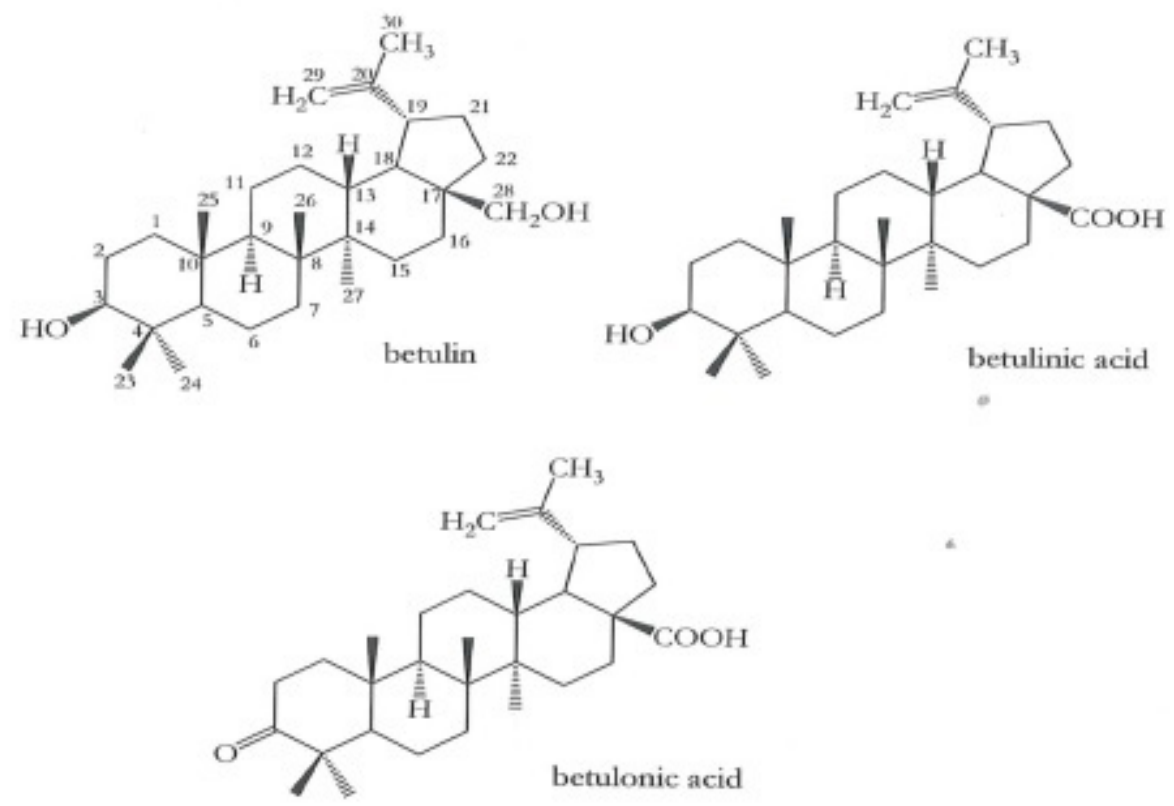

Figure 1: Structure of the natural active compounds

Methods of synthesis of many derivatives of BetA and betulonic acid have been described, including amino acid, amide as well as glycosides derivatives [7,8]. Several patents on BetA analogs for the chemotherapy of cancer have been reported. Most of these patents deal with modifications at positions C-3, C-20, and C-28 [9].

In this study, we tested the anti liver carcinoma activity of two cholesteryl ester derivatives of betulinic acid in C-28: the epicholesteryl betulinate is oil-soluble and its pegylated form is water-soluble [10].

\section{Why cholesterol as cancer recognized epitope?}

Cancer cells proliferate rapidly and require high cholesterol concentration [11].

Mullauer FB et al described that betulin, here the lesser active of the three triterpenes, is a potent anti-tumor agent that is enhanced by cholesterol [12].

Cholesterol is indeed essential for the development of the cell membrane and it is found in the lipid rafts of all our cells.

It is, therefore, an essential nutrient for the cancer cell.

The antitumor pharmacological effects consist of triggering apoptosis via the mitochondrial pathway, regulating the cell cycle and the angiogenic pathway via a variety of factors, including different transcription factors [13].

\section{A case study}

The alcoholic patient, B.H. born 06 April 1956, suffering from liver cancer developed on cirrhosis was, the 24 of Dec.2015, considered as lost for the medicine.

During hospitalization in December 2015, decompensated cirrhosis on hepatocarcinoma with the presence of ascites was diagnosed with the invasion of the portal vein.

The abdominal CT scan performed showed a $12 \mathrm{~cm}$ hepatocarcinoma in the right lobe.

Given the lack of therapy, the patient, Dr. in veterinary medicine, refused palliative care and decided on an experimental treatment by oral intake of two derivatives of betulinic acid. The Epicholesteryl betulinate and the Pegylated 3' a-cholesteryl betulinate. 


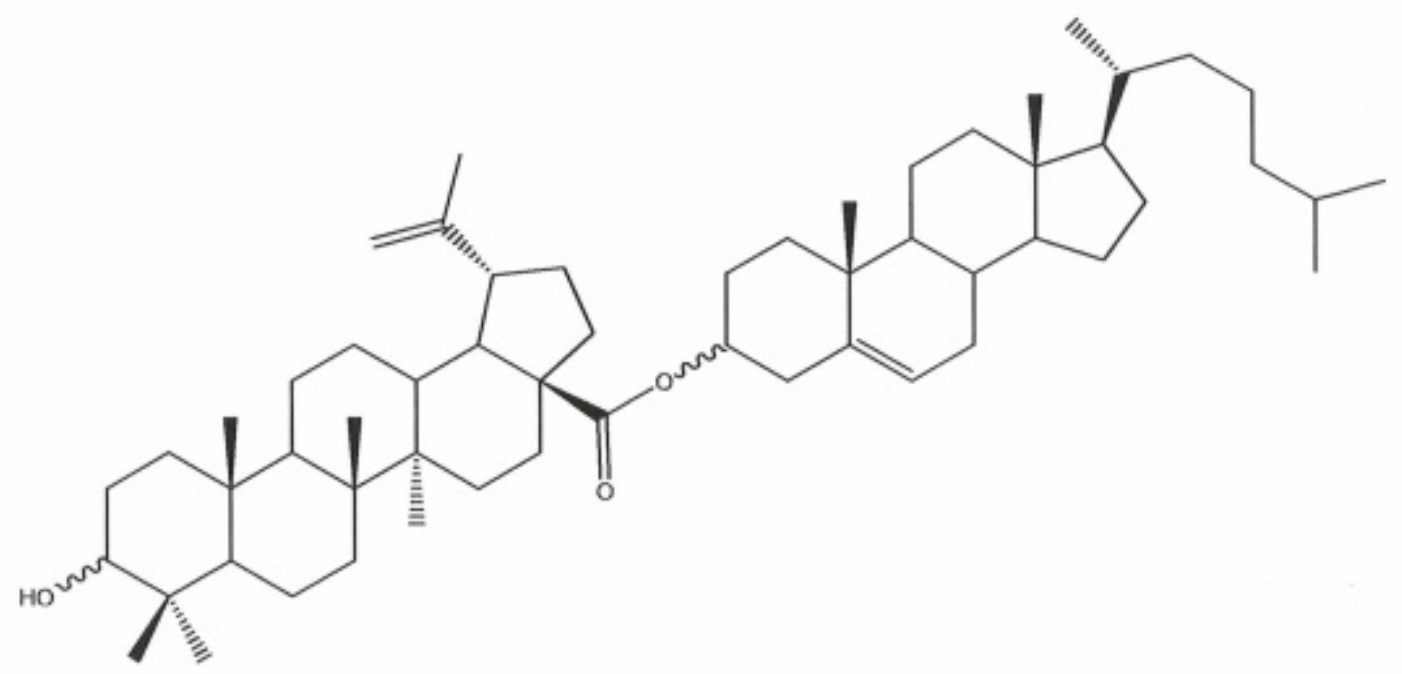

Figure 2: The Epicholesteryl betulinate

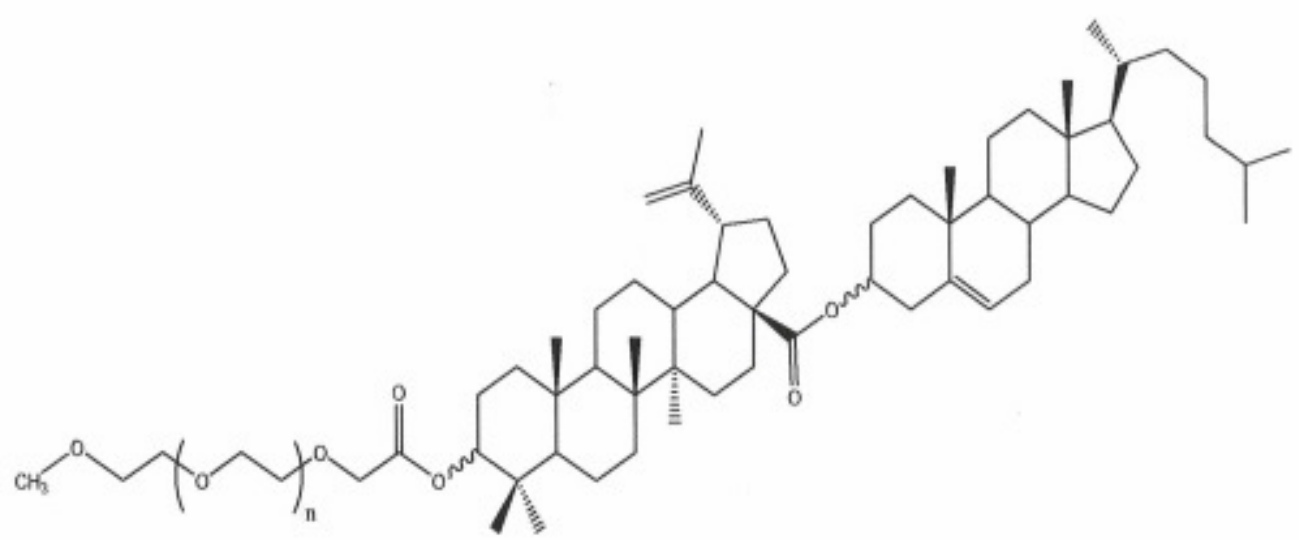

Figure 3: The pegylated 3' a-cholesteryl betulinate

The synthesis of those derivatives is described in the patents [7]. 


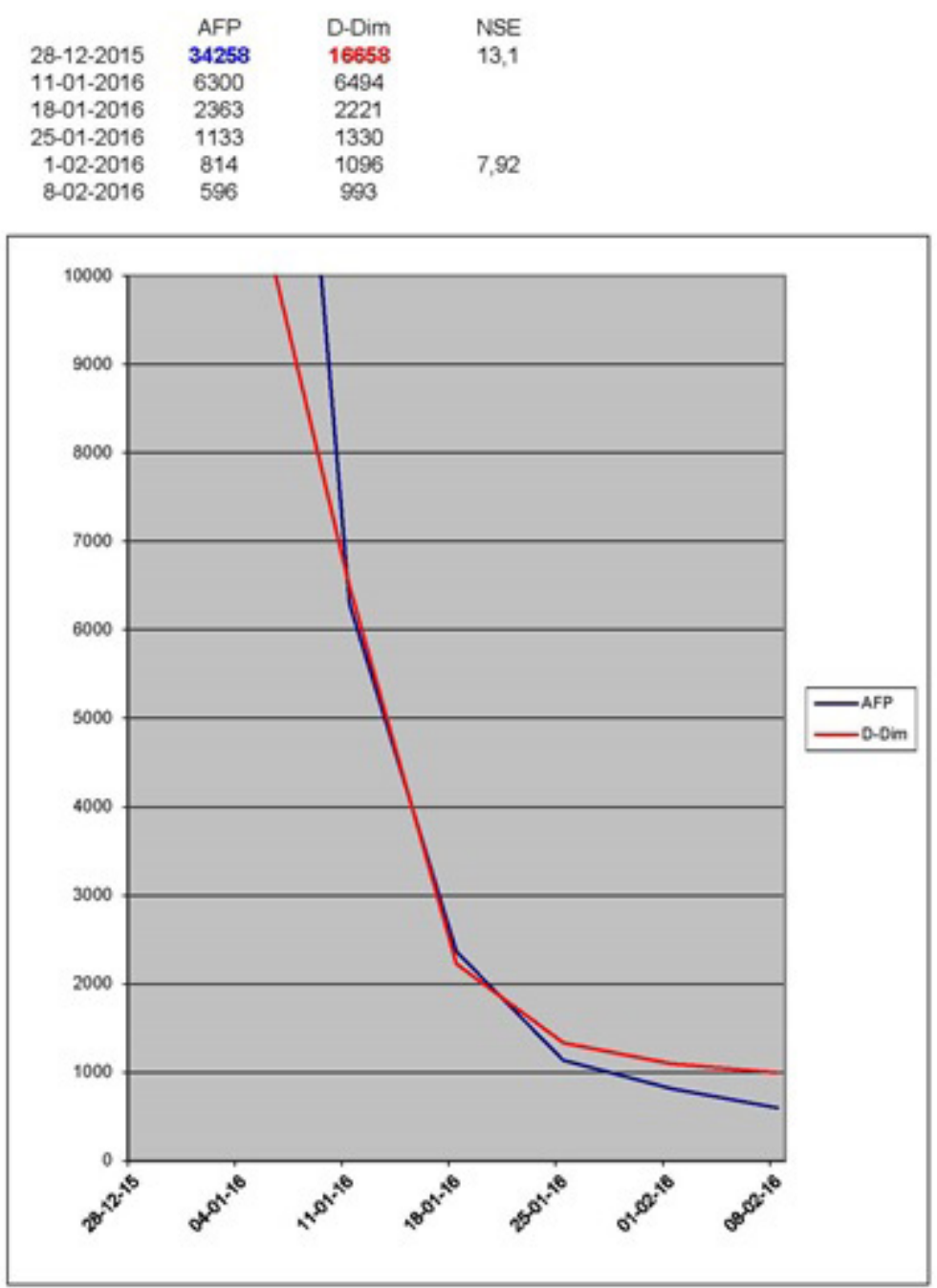

Figure 4

On the Monday 28.12.15 his alpha-fetoprotein (AFP) level was at $32258 \mathrm{ng} / \mathrm{ml}$ and the D-dimers at $16658 \mathrm{ng} / \mathrm{ml}$.

During January 2016, he took per os the cholesteryl ester BetA derivative soluble in oil described in the patent. In February, for personal reasons, he took the water-soluble form.

The patient went back to work for a year but due to persistent alcohol abuse, treatment with a single drug [14] and the now well-documented tumor heterogeneity, resistance to treatment appeared, AFP levels reincreased and the patient died in February 2017. According to his caring doctors, the positive impact of the treatment is unquestionable. No negative side effect was observed.
In the following graph, we document the observed values of AFP and D-dimers and their evolution until February 2016.

The normal physiological values for the parameters shown in the graph are as follows :

Alpha-fetoprotein - AFP : $<8 \mu \mathrm{g} / \mathrm{L}$

D-Dimers : $<500 \mathrm{ng} / \mathrm{ml}$

Neuro sensitive enolase - NSE - here not drawn : $<12 \mu \mathrm{g} / \mathrm{L}$

Report of the diagonistic finding are show in figure 5 


\section{Report on diagnostic findings on Circulating Tumor Cells (Maintrac)}

Dear Dr. Leunis,

Many thanks for sending your examination request regarding the detection of circulating tumor cells.

Diagnosis: $\quad$ Hepatocellular Carcinoma

The automated microfluorimetric image analysis of the epithelial cell antigen (HEA)-positive cells with visual control (MAINTRAC) from 1 ml EDTA blood resulted in following findings (detection limit is at 10 cells $/ \mathrm{ml}$ ):

\begin{tabular}{|c|c|c|c|c|}
\cline { 2 - 4 } \multicolumn{1}{c|}{} & \multicolumn{3}{c|}{ Number of potential tumor cells } & \multicolumn{1}{c|}{} \\
\hline $\begin{array}{c}\text { Examination } \\
\text { parameter }\end{array}$ & $\begin{array}{c}\text { In the sample } \\
(\mathrm{lml})\end{array}$ & $\begin{array}{c}\text { In circulation(5l) } \\
\text { (in millions) }\end{array}$ & $\begin{array}{c}\text { In addit examinction: } \\
\% \text { of HEA-pos cells }\end{array}$ & $\begin{array}{c}\text { Cell } \\
\text { fragments }\end{array}$ \\
\hline HEA & $\mathbf{1 0 0}$ & $\mathbf{0 , 5}$ & & some \\
\hline
\end{tabular}

The material you sent for examination could be thoroughly evaluated.

We found only a minimally to slightly increased number of vital tumor cells circulating in the blood. In addition, there were some specific ccll fragments detected. Specific cell fragments occur, for example, after chemotherapy or radiation, or as part of an immune response and indicate damaged cells.

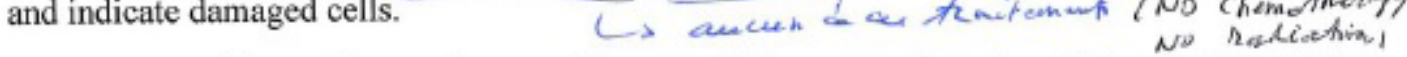

Under the condition of the prediagnosed hepatocellular cancer, there is a high probability that the cells are originating from this tumor. The low cell numbers, possibly is a result of previous therapies that first eliminates the circulating tumor cells. a debutaye batwats only

We would be grateful for more information relating to the time of the diagnosis and therapies possibly applied, so we could better evaluate the results.

The current cell numbers present a basic value, only an increase in cell numbers is relevant for disease progress. You now have a reference point, from which it can be determined if and how the number of these cells changes in response to therapy.

With best regards,

Dr. med. Ulrich Pachmann $\quad$ Prof. Dr. med. Katharina Pachmann $\quad$ Dr. med. Matthias Mäurer

Figure 5 


\section{References}

1. Pisha E. et al. (1995) Discovery of betulinic acid as a selective inhibitor of human melanoma that functions by induction of apoptosis. Nature Medicine 1: 1046-1051.

2. Fulda S. et al. (1997) Betulinic acid triggers CD95 (APO-1/ Fas)- and p53-independent apoptosis via activation of caspases in neuroectodermal tumors. Cancer Res. 57: 4956-4964.

3. Jäger S. et al. (2009) Pentacyclic triterpene distribution in various plants - rich sources for a new group of multi-potent plant extracts.Molecules14: 2016-31.

4. Krasutsky P.A (2006) Birch bark research and development. Nat. Prod. Rep 23: 919-942.

5. Kowalczyk T. et al. (2019) Induction of apoptosis by in vitro and in vivo plant extracts derived from Menyanthes trifoliata L. in human cancer cells. Cytotechnology 71: 165-180.

6. Zhang X. et al. (2016) Betulinic acid and the pharmacological effects of tumor suppression (Review). Mol. Med. Rep14: 44894495.

7. Flekhter OB, et al. (2004) [Synthesis and antiviral activity of amides and conjugates of betulonic acid with amino acids]. Bioorg Khim 30: 89-98.

8. Gauthier C et al. (2006) Glycosidation of lupane-type triterpenoids as potent in vitro cytotoxic agents. Bioorg. Med. Chem. 14: 6713-6725.

9. Csuk R (2014) Betulinic acid and its derivatives: a patent review (2008-2013). Expert Opin. Ther. Pat. 24: 913-923.

10. Leunis JC, Couché E EPO 1999139 and US 8,586,569 $9,303,058$ B2

11. Idippily ND, et al. (2017) Synthesis of Vorinostat and cholesterol conjugate to enhance the cancer cell uptake selectivity. Bioorganic Med Chem Lettb 27: 816-820.

12. Mullauer FB, et al. (2009) Betulin is a potent anti-tumor agent that is enhanced by cholesterol. PLoS ONE 2009 4: ePub

13. Safe S (2016) Natural Products as Mechanism-based Anticancer Agents: Sp Transcription Factors as Targets. Kasiappan R. Phytother. Res 30: 1723-1732.
14. Zhang C, et al. (2019) Oncogenic microRNA-411 promotes lung carcinogenesis by directly targeting suppressor genes SPRY4 and TXNIP. Oncogene 38: 1892-1904.

\footnotetext{
Submit your manuscript to a JScholar journal and benefit from:

๑ Convenient online submission

ฯ Rigorous peer review

ฯ Immediate publication on acceptance

ๆ Open access: articles freely available online

9 High visibility within the field

ฯ Better discount for your subsequent articles

Submit your manuscript at http://www.jscholaronline.org/submit-manuscript.php
} 